\title{
Will the World Cup change Brazil? Hosting a World Cup and the birth of new national narratives
}

\author{
Thomas Kühn ${ }^{1}$
}

\begin{abstract}
The article discusses the question why and how social psychologists should research the impact of having been the host of the World Cup for the Brazilian society. It will be argued that social psychologist should focus on changing national narratives, social representations and social imaginaries of being Brazilian. This approach should be related to research on collective action and collective emotions. Based on some qualitative projects conducted by the author in Germany and Brazil, the ambivalent character of modern national identity will be discussed. This ambivalence is grounded on different national narratives that are essential for the selfunderstanding of members from a nation. Hosting the World Cup has impacted on these fundamental narratives, already in anticipation of the event. Whereas expectations regarding the upcoming event were broadly skeptical and linked to fears, the experience of the event by itself included some positively attributed surprises. For some, the fearful view of "imagina na copa" turned into a proud "copa das copas" - though critics in regard to large spendings maintained. It can be assumed that having been the host of the World Cup, in the future will be embedded in national narratives and therefore will have impacts for Brazilian national identity.

Keywords: national identity; national narratives; collective pride; collective action; ambivalence.
\end{abstract}

\section{Introduction}

One could simply say: a World Cup means "party time" for about one month. From a critical perspective, one might add that it requires a very expensive investment to have such a party, and that only a small minority profits, while the majority has to pay for it. But beyond such economic considerations, what impact should a banal event like a FIFA? Soccer World Cup should have on the national identity?

There has been a lot of discussion in the media about whether Brazil will benefit from hosting the World Cup. These discussions mainly focus on the high financial costs spent for the preparation of the mega event. The aim of this article is not to contribute to this discussion of monetary aspects, but to examine how the meaning of the event can be understood from a social psychological perspective. It will be argued that by hosting a world cup the social representation of nationality changes within the population and in other countries. Social psychologists have to track those changes by doing research on national narratives and social imaginaries of nationality.

If we take the example of Germany, it is important to state: Hosting the World Cup in 2006 did indeed have an impact on the national identity. Before the World Cup it was not common to wave flags in a strongly visible way in public, as in the common understanding this was linked to a right-wing extremist nationalism. German citizens were very skeptical and distant towards the expression of national pride due to the Nazi regime and its consequences. Then, during the world Cup, many Germans experienced themselves in a very positive way: as friendly hosts, recognized by guests from all over the world.

\footnotetext{
${ }^{1}$ Senior Researcher at the University of Bremen; Director of the department for Social and Market Psychology within the Institute for Psychology and Transfer and faculty member of the Bremen International Graduate School of Social Sciences (BIGSSS) - Bremen, Germany. E-mail: thomas.kuehn@uni-bremen.de.
} 
Since then, one can't understand Germany and its national identity without referring to the World Cup 2006. This becomes clear in interviews with German citizens about their national identity. For Germans, the World Cup marked a change in the understanding of their own nationality. Still, there is confusion about what it really means to be German in a globalized world (cf. Kühn, 2014b), but hosting the World Cup gave birth to a new selfunderstanding and related reflections on German national identity, including questions of migration and integration - as watching players like Özil, Boateng and Khedira being natural parts of the German team unity challenged old narratives about being German.

For Brazil it is an open question as to how narratives of Brazilian identity will change in relation to hosting the World Cup. Based on qualitative research I have been conducting before and during the World Cup, some changes and possible future developments will be discussed in the third section. In the next section, I will discuss how social psychology should focus on changing national narratives and its meaning for national identity.

\section{Understanding national identities in a globalized world by focusing on social imaginaries and national narratives}

As the meaning of nationality has changed within the last few decades (e.g. Aronczyk, 2013; Özkirimli, 2010), the important question arises of how belongingness is constructed in an increasingly globalized social world. The greater importance of transnational structures and interactions does not mean that the meaning of nationality becomes obsolete because we still live in a world where nations are one of the main pillars of social order. Even if the meaning of nations is changing, nations continue to be a crucial category for one's own belonging to the modern world and to opportunity structures that are strongly linked to one's own citizenship and related social positioning in the world of international relations.

Therefore it is crucial for social psychologists to focus on construction processes of national identities. National identity describes the way how individuals construct belonging to a social group which forms a nation. Consequently, national identity is a particular form of collective identity. Nations are a cornerstone of modernity (Greenfeld, 2005). At the same time, we emphasize that nations have to be understood as a social construction in the sense of "imagined communities", which are influenced by reflections from members of a social group (cf. Anderson, 1983; Ismer, 2014). In this sense, national identity is always a subjective and discursive construction that at the same time is not built beyond social contexts, but is embedded in historically grown cultural surroundings.

Although we assume that nations are subjectively imagined and constructed in this sense, it is not an arbitrary act. Identity always has to be understood as a storied construction in which the present is put into relation to the past and the future. This also applies to national identity, which can only be constructed by a telling a narrative of the own nation in a specific way and by considering alternative narratives that might make a person prouder to be a member of a nation. National identity is built on specific understandings of one's own nation and nationhood: Which stories are told about the country within a country? This is called a national narrative. Within national narratives, iconic historic key moments of a country are embedded and tied up to a story that makes sense and explains the current situation in the world. 
Reicher and Hopkins (2001) have analyzed the construction process of national narratives that connects different iconic moments of national history to a narrative to provide a background foil for understanding the present and to mobilize for strategic considerations regarding the future. National narratives are not fixed, but in the course of history changeable and flexible, as a historical event may be interpreted quite differently dependent on one' $s$ own perspective and social positioning in a society. Due to social changes, national narratives are always fluent have to be updated to new challenges in a more and more globalized world. We can assume that different national narratives exist at the same time in a society and that also related iconic moments and national symbols are interpreted and linked in a different way.

Sociologists such as Rosa (2013) characterize late modernity as an age characterized by a high degree of uncertainties, ambivalences and ambiguities. This has to be considered when we examine the construction processes of national identity. Therefore it is important to avoid essentializing, mythologizing and homogenizing different national cultures. If we only asked for attitudes regarding one's own nation, we would not be able to capture gaps, e.g. between an expressed self-reflected distance regarding national belonging on the one hand and displayed strong group-based or collective emotions to one's own nationality, e.g. during mega-sports events. In a globalized world, national identities have to deal with ambivalences. This becomes particularly evident when one compares how, on the one hand, the importance of nationality is consciously reflected and, on the other hand, references to one's own nationality are implicitly embedded into the description of one's own daily life and biography. Respondents are usually unaware of how complex their references to their own nationality are (cf. Miller-Idriss \& Rothenberg, 2012).

In order to understand this complex relation of individuals to their membership in a nation it is useful to rely to social representations (Moscovici, 1988) or to use the term "social imaginary" that has been elaborated by the Canadian philosopher Charles Taylor (2004) to describe symbolic knowledge that controls our perceptions, emotions and actions. Social representations or imaginaries can be understood as a ground for one's own biographical decisions and everyday action.

It is important, therefore, to consider everyday actions of members of a nation and link these actions to the ways in which membership of a nationality or national group is reflected - both in terms of citizenship and being part of an imagined ethnic group. Research has to shift the focus to everyday life (e.g. Edensor, 2002, Fox \& Miller-Idriss, 2008) and this is why the complex dynamics of collective emotions - such as national pride, but also collective shame, indignation and anger - need to be understood and addressed (Sullivan, 2014).

When we focus on national identity, banal expressions of nationalism (Billig, 1995) in everyday life have to be captured as well the emotional attachment of individuals to their imagined nationality that they display during special occasions, such as mega-sports and political events. Smith (1998), for example, stresses that national identity is based on shared figures of interpretation of historical events and myths.

\section{The meaning of hosting the World Cup 2014 for national narratives in Brazil}

The following discussion is based on several research projects that were conducted by the author in Brazil since 2003. These projects are based on qualitative interviews (cf. Kühn 
2014a, 2014b, 2007) with Brazilian citizens from different social classes and groups. Two projects are especially crucial for this article. One project was conducted in December 2012 and January 2013 in cooperation with students of Political Sciences from the Universidade Federal Fluminense (UFF) in Niterói. Twenty qualitative interviews conducted with participants from different social classes in the state of Rio de Janeiro focused on Brazilian national identity and its linkage to everyday life. Within these interviews, the perception of the upcoming World Cup was one main topic. Currently, I am conducting another qualitative study in Brazil based on interviews with Brazilians about their experience of the manifestations in June 2013 and the World Cup in 2014.

A first finding is that anticipating the World Cup had an impact on national narratives and social imaginaries of Brazil as a nation. When talking about everyday life in Brazil in the year 2012, frequently the following phrase was mentioned by Brazilian citizens: "Imagina na Copa" ("Imagine this during the World Cup").

It has been used as a phrase to highlight strong discomfort with several social contexts in Brazil (cf. Kühn, 2014a), like being stuck in traffic jams or in overcrowded busses or metro trains. The phrase refers to the estimation that a country that is not even able to properly organize basic demands of social interaction in everyday life will not be able to manage a mega sports event. Respondents expressed their distrust in adequate organization and thought that corruption is the main reason for this. This is linked to an expression to a narrative of a Brazil that goes wrong and is seen as inferior in many aspects to other places in the world.

But this point of view is combined with a narrative of a powerful country that by its potential could and should be a giant. There is a positive view on a splendid Brazil that is rich by nature and has a marvelous population. Within this narrative, Brazil unifies the strengths of different origins and combines them into a unique power - all of this in a country that has very rich natural resources and is also supposedly blessed by God. This narrative of a powerful giant and splendid country for example is mirrored in the cover story of the popular journal "O Dia" from July $14^{\text {th }}, 2014$, after the World Cup final: "O papa é argentino, mas Deus é brasileiro" ("The Pope is from Argentine, but God is Brazilian").

Such an ambivalent Brazilian identity based on different narratives was the base for the protests that took place in June 2013 during the Confederations Cup (cf. Kühn, 2014a). On the one hand, protests were related to shared emotions of anger, frustration and indignation, but on the other hand, also there was a strong national pride and belief in the power of the nation. That the World Cup would take place in the next year was in the mind of the protesters. It facilitated the public expression of the message that Brazilian people are no longer willing to accept a bad administration without resistance. The occurrence of these manifestations already changed the Brazilian national narrative of being nice and cordial, but not able to unify and fight for more influence, power and justice. The slogan of the protests was: "O gigante acordou" ("the giant woke up"). It expressed a strong wish to be recognized as a modern and powerful country and as part of a globalized world. A new narrative was born: Brazil that has a strong population that is tired of having to accept everything and to suffer in life due to an (imagined) bad administration.

In 2014, there was no similar wave of public protests. In the interviews that were conducted during the last days of the World Cup, several respondents who sympathize with the protestors of 2013, point out that it has been important for them that during the World 
Cup Brazil presented itself as friendly host. Though they liked the protests in 2013, their occurrence in a similar size would have caused shame during times of the World Cup for them. "Imagina na copa" turned into "A copa das copas" ("The World Cup of all World Cups") and a base for the experience of national pride. This pride was expressed by fans in the stadiums, singing "Sou brasileiro com muito orgulho e muito amor" ("I am Brazilian with a lot of pride and a lot of love"). This does neither mean that their distant attitude regarding Brazilian politicians changed, neither that they changed their positive attitude regarding public manifestations, but the World Cup has greater symbolic value than the Confederations Cup.

Neither traffic jams, neither violence were imprinted on the public image of the World Cup, but there were great games and tourists were impressed by friendly hosts and by a country that apparently was able to organize a great tournament in a very smooth and attractive manner. But though, as our interviews demonstrate, also within parts of the population maintains a lot of distance to the event due to the high amounts of money invested in stadiums which further usage is not clear in all regions of Brazil. After the World Cup, Brazilians tell different stories about it, ranging from accounts of a successful event that empowered the population to a country that missed an opportunity or never should have hosted it.

In the media there have been a lot of discussions on the meaning of the lost game of the Brazilian "seleção" against Germany and its long-term impact for Brazilian identity, by linking the outcome of the game to feelings of humiliation and "shame forever". But, as the German example shows, it could be also a chance. It could be the rise of a narrative of a Brazil that impresses and surprises not mainly by its soccer team, but by being able to host a great mega sports event, a country that can be serious without necessarily turning into a threatening and dominating giant. In 2006, although Germany lost once again to Italy in the semi-finals, the World Cup was an important turning point for national narratives.

Our interviews show that it's an open question how the World Cup will be remembered within Brazil. There will be different and competing narratives, embedding the World Cup in more positive and more negative contexts. But when Brazilians tell their story of Brazil, the World Cup will have a meaning that can't be ignored. This is why it is important for social psychologists to examine the importance of mega sports events like the World Cup for national narratives.

\section{References}

Anderson, B. (1983). Imagined Communities: Reflections on the Origin and Spread of Nationalism. London: Verso.

Aronczyk, M. (2013). Branding the Nation: The Global Business of National Identity. Oxford, New York: Oxford University Press.

Billig, M. (1995). Banal nationalism. London: Sage.

Edensor, T. (2002). National Identity, Popular Culture and Everyday Life. Oxford, New York: Berg.

Fox, J. E., \& Miller-Idriss, C. (2008). Everyday Nationhood. Ethnicities, 8, 536-563.

Greenfeld, L. (2005). Nationalism and the mind. Nations and Nationalism, 11(3), 325-341. 
Ismer, S. (2014). Collective emotions and the imagined national community. In G. B. Sullivan (Ed.). Understanding Collective Pride and Group Identity: New directions in emotion theory, research and practice (pp. 137-148). London: Routledge.

Kühn, T. (2007). Condução da vida cotidiana e desigualdade social: um estudo explorativo em Salvador da Bahia. In J. Souza \& P. Mattos (Eds.). Teoria crítica no século XXI (pp. 303-318). São Paulo: Annablume.

Kühn, T. (2014a). Construction of belongingness in late modernity: national pride in Brazil from a social inequality research perspective. In G. B. Sullivan (Ed.). Understanding Collective Pride and Group Identity: New directions in emotion theory, research and practice (pp. 161-172). London: Routledge.

Kühn, T. (2014b, in press). Kritische Sozialpsychologie des modernen Alltags. Zum Potenzial einer am Lebenslauf orientierten Forschungsperspektive. Wiesbaden: Springer VS.

Miller-Idriss, C., \& Rothenberg, B. (2012). Ambivalence, Pride, and Shame: Conceptualizations of German Nationhood. Nations \& Nationalism, 18(1), 132-135.

Moscovici, S. (1988). Notes towards a description of social representations. Journal of European Social Psychology, 18(3), 211-250.

Özkirimli, U. (2010). Theories of Nationalism: A Critical Introduction. Houndmills, Basingstoke, New York: Palgrave Macmillan.

Reicher, S. D., \& Hopkins, N. (2001). Self and Nation. London, Thousand Oaks, New Delhi: Sage.

Rosa, H. (2013). Social Acceleration: A New Theory of Modernity (New Directions in Critical Theory). New York: Columbia University Press.

Smith, A. D. (1998). Nationalism and Modernism. London: Routledge.

Souza, J., \& Mattos, P. (Eds.) (2007). Teoria crítica no século XXI. São Paulo: Annablume.

Sullivan, G.B. (Ed.) (2014). Understanding Collective Pride and Group Identity: New directions in emotion theory, research and practice. London: Routledge.

Taylor, C. (2004). Modern Social Imaginaries. Durham: Duke University Press. 